\title{
ANALISIS PROFIL USAHA DAN PENDAPATAN PENGOLAH VIRGIN COCONUT OIL (VCO) DI DESA HORONGKULI
}

\author{
Aan Pratama Rusli1), Andi Mega Mustika1), Nur Ilmiah'), Bergas Kudiangga1), \\ Hasbiadi'2), Asni') $^{2}$ \\ ${ }^{1}$ Mahasiswa Program Studi Agribisnis, Universitas Sembilanbelas November Kolaka \\ 2Dosen Program Studi Agribisnis, Universitas Sembilanbelas November Kolaka \\ *Email Korespondensi : anggamentari123@gmail.com
}

\begin{abstract}
Abstrak
Desa Horongkuli merupakan daerah yang sangat potensial untuk pengembangan usaha minyak kelapa murni atau virgin coconut oil (VCO). Sebagian besar terdiri dari daerah pesisir yang ditumbuhi pohon kelapa, yang dapat mendukung pengembangan bisnis VCO karena bahan baku yang dibutuhkan dapat dengan mudah dipenuhi. Penelitian ini bertujuan untuk mengetahui profil usaha Pengolah VCO dan untuk mengetahui pendapatan Pengolah VCO di Desa Horongkuli. Metode penelitian yang digunakan yaitu metode survei dengan teknik purposive sampling. Objek dalam penelitian yaitu pengolah VCO dengan skala home industry di desa Horongkuli. Analisis data yang digunakan adalah analisis deskriptif dan analisis pendapatan. Profil usaha pengolah VCO di Desa Horongkuli menggunakan bahan baku kelapa lokal dan peralatan yang sederhana dalam mengolah VCO, serta jumlah pendapatan yang diterima pengolah VCO yaitu sebesar Rp 833.250 perbulan dengan nilai $\mathrm{r} / \mathrm{c}$ ratio 1,295 artinya layak diusahakan.
\end{abstract}

Kata kunci: Pendapatan, Petani Kelapa, Profil Usaha

\begin{abstract}
Horongkuli village is a very potential area for the development business of virgin coconut oil (VCO). Most of it consists of coastal areas overgrown with coconut trees, which can support the development of the VCO business because the raw materials needed can be easily met. This study aims to determine the business profile of VCO processors and to determine the income of VCO processors in Horongkuli Village. The research method used is survey method with purposive sampling technique. The object of the research is VCO processing with a home industry scale in Horongkuli village. The data analysis used is descriptive analysis and income analysis. The profile of the VCO processing business in Horongkuli Village uses local coconut raw materials and simple equipment in processing VCO, and the amount of income received by the VCO processor is Rp. 833,250 per month with an $\mathrm{r} / \mathrm{c}$ ratio of 1.295 which means it is feasible
\end{abstract}

Keywords: Business Profile, Coconut Farmers, Income 


\section{PENDAHULUAN}

Kelapa (Cocos Nucifera) adalah satu jenis tumbuhan dari keluarga Arecaceae, termasuk jenis tanaman palma yang mempunyai buah berukuran cukup besar. Batang pohonnya umumnya berdiri tegak dan tidak bercabang, dan dapat mencapai 10-14 meter lebih. Daunnya berpelepah, panjangnya dapat mencapai 3-4 meter lebih dengan sirip-sirip lidi yang menopang tiap helaian. Buahnya terbungkus dengan serabut dan batok yang cukup kuat, sehingga untuk memperoleh buahnya harus dikuliti terlebih dahulu. Pohon yang sudah besar dan subur, dapat menghasilkan 2-10 buah tiap tangkainya. Adapun struktur buah kelapa terdiri dari sabut (35\%), daging buah (28\%), air kelapa (15\%), tempurung (12\%), serta bagian lainnya (tongkol buah, kulit luar, lembaga dan testa). Hampir semua bagian kelapa tersebut bisa dimanfaatkan, tetapi daging buah merupakan bagian yang paling banyak dimanfaatkan untuk bahan makanan dan bahan baku industri. Produksi kelapa Indonesia merupakan salah satu yang terbesar di dunia dengan produksi sebesar 18,30 juta ton per tahun serta pangsa pasarnya sebesar $30,24 \%$ dari produksi kelapa dunia. Produksi kelapa Indonesia saat ini terkonsentrasi di beberapa pulau besar yaitu Sumatera, Jawa, dan Sulawesi dengan rata-rata produktivitas pada tahun 2014 sebesar 11,36 ton/hektar (Sukmaya, 2017). Produktivitas ini sudah di atas rata-rata produktivitas kelapa dunia sebesar 5,20 ton/hektar. Sebagian besar produk kelapa Indonesia merupakan komoditas ekspor, penggunaan untuk konsumsi domestik lebih sedikit. Usaha pengolahan produk turunan kelapa berpotensi untuk dikembangkan di daerah-daerah sentra produksi karena bahan bakunya yang melimpah. Berdasarkan analisis finansial, usaha produk turunan kelapa layak dikembangkan dan menunjukkan keuntungan yang terus meningkat setiap tahunnya (Kuswanto, 2012; Boekoesoe, et.al, 2015; Setyawan dan Purwanti, 2016).

Pada umumnya di Indonesia kelapa diproduksi untuk menghasilkan kopra yang diambil daging buahnya sebagai bahan baku minyak kelapa dan digunakan sebagai minyak goreng. Minyak kelapa produksi Indonesia selama ini telah di ekspor, namun hasil ekspor tersebut Indonesia masih belum bisa memperoleh keuntungan yang besar. Nilai ekspor minyak kelapa Indonesia hanya 32,2 persen dari total ekspor dunia, masih dibawah Filipina yang sebesar 45,6 persen (Setiawan, 2002), padahal daya serap pasar dunia tergolong tinggi. Masyarakat di Eropa Barat memerlukan 570.000 ton minyak kelapa (20,3 persen dari pasar dunia), Amerika Serikat 467.000 ton (16,6 persen), dan India 451.000 ton (16,1 persen).

Selain volume ekspor yang rendah, Indonesia juga belum mengembangkan produk minyak yang bernilai jual tinggi, karena ekspor Indonesia masih dalam bentuk minyak kelapa biasa, sedangkan Filipina telah memproduksi minyak kelapa dara murni (Virgin Coconut Oil/VCO) yang harganya bisa mencapai tiga sampai empat kali minyak kelapa biasa. VCO mempunyai nilai tambah yang besar karena dapat digunakan sebagai bahan baku berbagai produk seperti kosmetik, sabun, makanan dan obat-obatan. Permintaan VCO tidak hanya datang dari dalam negeri tetapi juga dari luar negeri. Kebutuhan Amerika terhadap VCO sekitar 1000 ton per tahun, 600 ton teRp.enuhi dari hasil impor dari Filipina. Denmark memerlukan 500 ton per tahun dan Inggris memerlukan 250 ton per tahun (Trubus, 2005). Dari data tersebut, menunjukkan bahwa VCO memiliki prospek yang baik, apalagi ditunjang dengan harga yang cukup tinggi. Di pasaran VCO dijual dengan harga bervariasi antara Rp. 35.000 sampai dengan Rp. 50.000 per $350 \mathrm{ml}$ tergantung kandungan asam lauratnya. Standar mutu ekspor yang harus dipenuhi VCO adalah kadar asam laurat 43-53 persen, asam kaproat 0,4-0,6 persen, asam kaprat 4,5-8 persen, peroksida $3 \mathrm{mg}$ per $\mathrm{kg}$, arsenik 0,1 mg per kg dan tembaga 0,4 mg per $\mathrm{kg}$. 
Kelapa (Cocos Nucifera) merupakan komoditas yang penting bagi rakyat Indonesia dan dapat menjadi penggerak ekonomi rakyat. Hal itu dapat dilihat dari pengelolaan pertanaman kelapa di Indonesia yang sebagian besar dikelola oleh rumah tangga petani. Tanaman kelapa merupakan tanaman serbaguna yang mempunyai nilai ekonomi tinggi. Hampir seluruh bagian pohon, akar, batang, daun sampai buahnya dapat digunakan untuk kebutuhan kehidupan sehari-hari. Kelapa merupakan salah satu komoditas perkebunan yang cukup banyak dibudidayakan di Desa Horongkuli Kabupaten Kolaka.

Bagian utama kelapa yang dimanfaatkan adalah daging buah kelapa. Umumnya daging kelapa hanya dimanfaatkan untuk membuat kopra, padahal buah kelapa dapat dimanfaatkan menjadi berbagai macam produk. Oleh karena itu, perlu dilakukan diversifikasi produk kelapa menjadi produk lain yang memiliki nilai jual tinggi. Salah satu produk diversifikasi dari buah kelapa adalah minyak kelapa murni atau VCO. Pembuatan minyak kelapa dengan memancing minyak dalam santan dengan minyak kelapa. Teknologi ini memanfaatkan reaksi kimia sederhana, dimana santan adalah campuran air dan minyak. Kedua senyawa ini bisa bersatu karena adanya molekul protein yang menelilingi molekul-molekul minyak. Dengan teknik pemancingan, molekul minyak dalam santan ditarik oleh minyak umpan sampai akhirnya bersatu. Tarikan itu membuat minyak terlepas dari air dan protein. Minyak yang dihasilkan adalah minyak kelapa dengan kualitas tinggi yang disebut Virgin Coconut Oil (VCO). VCO merupakan salah satu produk dari sari pati kelapa yang telah diketahui sangat baik bagi kesehatan. Kandungan VCO yang hampir 50\% mengandung asam laurat (C-12) menyebabkan efek kesehatan dari VCO hampir sama dengan air susu ibu (ASI). Hal ini dikarenakan asam laurat dalam tubuh manusia akan diubah menjadi monolaurin. Monolaurin sendiri bersifat sebagai antivirus, antibakteri, dan antiprotozoa. Hasil penelitian menunjukkan, bahwa monolaurin dapat merusak membran lipid virus diantaranya virus HIV, influenza, hepatitis C, dan cytomelagovirus.

Desa Horongkuli merupakan daerah yang potensial untuk pengembangan VCO karena sebagian besar wilayahnya merupakan daerah pantai yang ditumbuhi tanaman kelapa. Kondisi ini sangat mendukung pengembangan VCO, karena kebutuhan bahan baku buah kelapa dapat dipenuhi dengan mudah. Kondisi wilayah yang banyak terdapat pohon kelapa merupakan alasan paling utama pengembangan usaha VCO, selain itu diharapkan dapat meningkatkan nilai tambah dan juga pendapatan yang diperoleh petani kelapa pada umumnya mengingat prospek pasar VCO cukup bagus, baik pasar dalam negeri maupun luar negeri ditambah harga yang cukup mahal, tentunya akan meningkatkan pendapatan petani kelapa. Adanya usaha ini diharapkan mampu menyerap tenaga kerja lokal sehingga dapat mengurangi pengangguran dan dapat meningkatkan PAD (Pendapatan Asli Daerah).

Harga buah kelapa di pasaran tidak selalu stabil. Harga kelapa dapat menjadi sangat rendah dan juga sangat tinggi. Petani kelapa selama ini sering dirugikan karena harga yang sangat rendah, apalagi biasanya petani berada pada pihak yang lemah. Harga yang rendah mengakibatkan petani tidak melakukan perawatan khusus terhadap tanaman kelapa sehinga berpengaruh terhadap produktivitas tanaman, walaupun tanaman kelapa memiliki toleransi sangat tinggi terhadap lingkungan hidupnya. Karena pada saat panen harga kelapa rendah maka banyak kelapa tidak termanfaatkan karena petani lebih suka membiarkan buah kelapa daripada menjualnya dengan harga yang rendah. Permintaan pasar terhadap kelapa di Indonesia tergantung pada musim tertentu. Mendekati bulan puasa dan hari raya biasanya permintaan kelapa meningkat, namun di luar musim tersebut permintaan kelapa tidak terlalu banyak sehingga banyak sekali yang tidak terserap pasar. Adanya usaha pembuatan VCO, diharapkan dapat memberikan solusi bagi pemasaran buah kelapa, sehingga tidak lagi fluktuatif seperti sebelumnya. Dengan demikian harga buah kelapa relatif stabil karena permintaannya cenderung stabil setiap bulan. Sehubungan dengan hal tersebut maka rumusan masalah dalam penelitian ini yaitu 
1)Bagaimana profil usaha Pengolah VCO di Desa Horongkuli, 2)Bagaimana pendapatan Pengolah VCO di Desa Horongkuli. Tujuan penelitian ini antara lain 1)Untuk mengetahui profil usaha Pengolah VCO di Desa Horongkuli, 2)Untuk mengetahui pendapatan Pengolah VCO di Desa Horongkuli.

Penelitian ini diharapkan bermanfaat bagi petani kelapa untuk memberikan informasi mengenai peluang dan potensi pengembangan usaha VCO yang dapat menambah pendapatan dan bagi pengusaha VCO dapat memberikan gambaran usahanya sehingga dapat dijadikan landasan untuk mengembangkan usahanya di masa yang akan datang. Selain itu bagi pemerintah, hasil penelitian ini diharapkan dapat dijadikan sebagai bahan pertimbangan dan masukan dalam menyusun berbagai strategi kebijakan dan pengembangan usaha pembuatan VCO.

\section{METODE PENELITIAN}

Penelitian ini merupakan penelitian survei dan menggunakan teknik purposive sampling (penentuan sampel secara sengaja). Dalam hal ini, Desa Horongkuli dipilih sebagai tempat penelitian dengan objek penelitian yaitu Masyarakat atau Pengolah VCO. Penelitian dilaksanakan selama satu bulan pada bulan April 2021 di Desa Horongkuli Kabupaten Kolaka. Data penelitian yang diambil meliputi data profil usaha VCO, penggunaan faktor produksi, jumlah produk, biaya produksi, harga produk, dan keuntungan. Data yang diambil adalah data primer. Data primer diperoleh dari responden yaitu industri rumah tangga VCO yang merupakan mitra atau binaan desa horongkuli, Badan Pusat Statistik dan pustaka yang berkaitan dengan permasalahan yang dibahas dalam penelitian ini. Metode analisis dilakukan dengan pendekatan:

1. Analisis deskriptif untuk menggambarkan profil usaha VCO di Desa Horongkuli Kabupaten Kolaka

2. Analisis Biaya

Menurut Suratiyah (2015), untuk menghitung besarnya total biaya (Total Cost) diperoleh dengan cara menjumlahkan biaya tetap (Fixed Cost) dengan biaya variabel (Variable Cost) dengan rumus :

$$
\mathrm{TC}=\mathrm{FC}+\mathrm{VC}
$$

Dimana :

$$
\begin{aligned}
& \mathrm{TC}=\text { Total Cost }(\text { Total Biaya }) \\
& \mathrm{FC}=\text { Fixed Cost (Biaya Tetap) } \\
& \text { VC }=\text { Variable Cost (Biaya Variabel) }
\end{aligned}
$$

3. Analisis Pendapatan

Menurut Suratiyah (2015), pendapatan adalah selisih antara penerimaan (TR) dan biaya total (TC) dan dinyatakan dengan rumus:

$$
\mathrm{I}=\mathrm{TR}-\mathrm{TC}
$$

Dimana :

$$
\begin{aligned}
& \text { I = Income (Pendapatan) } \\
& \mathrm{TR}=\text { Total Revenue (Penerimaan Total) } \\
& \mathrm{TC}=\text { Total Cost (Biaya Total) }
\end{aligned}
$$

4. Analisis R/C

Menurut Suratiyah (2015), R/C adalah perbandingan antara penerimaan dengan total biaya.

$$
\mathrm{R} / \mathrm{C}=\frac{\text { Penerimaan Total }(\mathrm{TR})}{\text { Biaya Total }(\mathrm{TC})}
$$


Dimana :

$\mathrm{TR}=$ Total Penerimaan

$\mathrm{TC}=$ Total Biaya

Kriteria penerimaan $\mathrm{R} / \mathrm{C}$ ratio :

$\mathrm{R} / \mathrm{C}<1$ = usaha produksi minyak kelapa murni mengalami kerugian.

$\mathrm{R} / \mathrm{C}>1$ = usaha produksi minyak kelapa murni memperoleh keuntungan.

$\mathrm{R} / \mathrm{C}=1$ = usaha produksi minyak kelapa murni mencapai titik impas

\section{HASIL DAN PEMBAHASAN}

\section{Profil Usaha Pengolah VCO}

Profil Usaha VCO Dari hasil penelitian diketahui bahwa usaha VCO di Desa Horongkuli menggunakan peralatan yang berupa mesin parut yang digunakan untuk memarut kelapa, mesin pres yang digunakan untuk memeras sari-sari kelapa yg telah di parut, baskom besar yang digunakan untuk menampung sari kelapa, dan golok yang digunakan untuk membelah buah kelapa menjadi dua. Peralatan lain yang digunakan untuk pembuatan VCO di Desa Horongkuli adalah pisau cukil yang digunakan untuk memisahkan isi dari temputung kelapa, linggis yang digunakan untuk mengupas sabuk kelapa, saringan yang digunakan untuk memisahkan sari kelapa dengan ampas kelapa, pengaduk yang digunakan untuk mengaduk yang sementara di masak agar tidak hangus, jerigen yang digunakan untuk menampung minyak hasil sangrai, dan selang yang digunakan untuk mengisi minyak kedalam botol kemasan. Ketersediaan dan keberadaan peralatan tersebut cukup memadai untuk mendukung beroperasinya usaha agroindustri VCO di Desa Horongkuli. Bahan baku utama dalam pembuatan VCO adalah kelapa. Bahan baku kelapa diperoleh pengrajin dari wilayah Desa Horongkuli. Ketersediaan bahan baku kelapa di daerah ini cukup melimpah sehingga pengrajin tidak mengalami kesulitan memperoleh bahan baku kelapa. Selain bahan baku pembuatan VCO juga didukung adanya tenaga kerja, kertas saring, kapas, minyak pancing, dan kemasan

Usaha pembuatan VCO di Desa Horongkuli merupakan industri rumah tangga. Bahan baku pembuatan produk berasal dari Desa Horongkuli dan daerah sekitarnya. Kebutuhan bahan baku utama pembuatan VCO berupa kelapa selama ini selalu terpenuhi karena ketersediaannya yang cukup melimpah. Bahan baku kelapa yang digunakan berkisar antara 2.400 buahsampai dengan 4.500 buah dengan rata-rata 13.000 butir per tahun. Jumlah produk VCO yang dihasilkan berkisar antara 800 sampai dengan 1000 liter per tahun.

\section{Keuntungan Usaha Pembuatan VCo}

Pengeluaran pengrajin untuk memperoleh bahan baku dan pendukung pembuatan VCO merupakan komponen biaya. Biaya dalam pembuatan VCO di Desa horongkuli terdiri dari biaya tetap dan biaya variabel. Biaya tetap yang diperhitungkan dalam pembuatan VCO hanya biaya penyusutan alat, biaya pajak tidak dimasukkan karena usaha pembuatan VCO di Desa Horongkuli merupakan usaha rumah tangga sehingga biaya pajak tidak diperhitungkan dalam perhitungan biaya tetap. Biaya variabel dalam pembuatan VCO terdiri dari biaya pembelian kelapa, biaya tenaga kerja, dan botol kemasan 
Tabel 1. Analisis Pendapatan Pengolah VCO di Desa Horongkuli Kabupaten Kolaka

\begin{tabular}{|c|c|c|c|}
\hline No & Uraian & Jumlah (Liter) & Jumlah \\
\hline 1. & $\begin{array}{ll}\text { Penerimaan (TR) } & =\mathbf{P} . \mathbf{Q} \\
\text { Produksi }(\mathrm{Q}) & \\
\text { Harga Produksi (P) } & \end{array}$ & 4,33 & 250.000 \\
\hline & Total Penerimaan & & 1.082 .50 \\
\hline 2. & $\begin{array}{l}\text { Biaya } \\
\text { a. } \text { Biaya Tetap (FC) } \\
\text { - Listrik } \\
\text { - Penyusutan alat } \\
\text { - Parang } \\
\text { - Pencungkil } \\
\text { - Ember } \\
\text { - Baskom besar } \\
\text { - Keranjang } \\
\text { - Mesin Parut kelapa } \\
\text { - Wadah plastik bening } \\
\text { - Corong } \\
\text { - Sendok } \\
\text { - Teko air plastik } \\
\text { - Selang bening/selang kecil }\end{array}$ & & $\begin{array}{l}100.000 \\
10.000 \\
5.000 \\
8.000 \\
10.000 \\
1.500 \\
35.000 \\
10.000 \\
1.800 \\
3.000 \\
1.500 \\
200\end{array}$ \\
\hline
\end{tabular}

\begin{tabular}{|c|c|c|}
\hline \multicolumn{2}{|r|}{ Total Biaya Tetap } & 186.000 \\
\hline \multicolumn{3}{|c|}{ b. Biaya Variabel (VC) } \\
\hline & - Botol & 7.000 \\
\hline & - Tenaga kerja penyediaan bahan baku & 150.000 \\
\hline & - Tenaga kerja pengolahan & 250.000 \\
\hline \multicolumn{2}{|r|}{ Total Biaya Variabel } & 457.000 \\
\hline \multicolumn{3}{|c|}{ 3. Total biaya (TC) $=\mathrm{FC}+\mathrm{VC}$} \\
\hline & a. Biaya tetap $(\mathrm{FC})$ & 186.000 \\
\hline & b. Biaya variabel (VC) & 457.000 \\
\hline \multicolumn{2}{|r|}{ Total Biaya Produksi } & 643.000 \\
\hline \multirow[t]{3}{*}{4.} & Pendapatan (Pd) & \\
\hline & a. Penerimaan & 1.082 .500 \\
\hline & b. Total Biaya & 643.000 \\
\hline \multicolumn{2}{|r|}{ Total Pendapatan } & 439.500 \\
\hline \multirow{3}{*}{\multicolumn{2}{|c|}{ 5. $\quad$ R/C Ratio }} & 1.082 .500 \\
\hline & & 643.000 \\
\hline & & 1,68 \\
\hline
\end{tabular}

Sumber: Data diolah 2021

Tabel 1 menunjukkan total penerimaan pengolah VCO adalah sebesar Rp 1.082.500, yang diperoleh dengan mengalikan jumlah produksi dengan harga produksi. Adapun total biaya yang dikeluarkan yaitu Rp 643.000 dari penjumlahan biaya tetap Rp 186.000 dengan biaya variabel Rp 457.000. Total pendapatan pengolah VCO diperoleh dari total peneriamaan dikurangi total biaya, sehingga didapat keseluruhan pendapatan Pengolah VCO di Desa Horongkuli yaitu sebesar Rp 439.500 dalam satu bulan produksi. Tujuan utama usaha VCO adalah untuk memperoleh pendapatan maksimum yang merupakan cara untuk meningkatkan taraf hidup yang lebih baik. Pendapatan yang diperoleh didistribusikan untuk (1) kegiatan produktif antara lain untuk membiayai usaha, (2) 
kegiatan konsumtif antara lain untuk memenuhi kebutuhan pangan, sandang papan, kesehatan, rekreasi, dan pajak, (3) pemeliharaan investasi, dan (4) investasi dan tabungan. Lebih lanjut dengan nilai $\mathrm{R} / \mathrm{C}$ ratio yang cukup tinggi yaitu 1,68 maka usaha pengolah VCO menguntungkan dan layak untuk dilakukan. Hal ini sejalan dengan penelitian yang dilakukan oleh Asnidar dan Asrida (2017) dengan judul penelitian analisis kelayakan usaha home industry kerupuk opak di Desa Paloh Meunasah Dayah Kecamatan Muara Satu Kabupaten Aceh Utara, yang menyatakan bahwa dengan nilai r/c ratio lebih besar dari satu maka usaha tersebut laya diusahakan dan menguntungkan.

Rekomendasi pengembangan VCO di Desa Horongkuli meliputi lebih mengintensifkan penggalian dana yang bersumber dari modal sendiri, menjalin kerjasama untuk mencari mitra usaha yang saling menguntungkan, mengembangkan program kerjasama yang masih memungkinkan dan menguntungkan, mengembangkan promosi dan pemasaran produk yang dihasilkan dilakukan dengan melakukan kerjasama dengan lembaga lain, dan efisiensi dan skala prioritas dalam penggunaan dana pinjaman. Hal ini sejalan dengan penelitian yang telah dilakukan oleh Kindangen (2007) yang menganalisis kelayakan usaha pengembangan industri kelapa terpadu skala pedesaan di Sulawesi Utara.

\section{KESIMPULAN}

Kesimpulan dalam penelitian ini antara lain profil usaha pengolah VCO di Desa Horongkuli yaitu menggunakan bahan baku kelapa lokal dan peralatan yang sederhana dalam mengolah VCO. Selanjutnya jumlah pendapatan yang diterima pengolah VCO yaitu sebesar Rp 439.500 perbulan dengan nilai r/c ratio 1,68 artinya layak diusahakan.

\section{UCAPAN TERIMA KASIH}

Dalam pembuatan artikel ini kami mengucapkan banyak terima kasih kepada Perangkat Desa Horongkuli Kabupaten Kolaka yang telah mendukung dan menfasilitasi kegiatan penelitian ini serta kami ucapkan terima kasih kepada Dosen Pengampuh Mata Kuliah Pengantar Agroindustri Program Studi Agribisnis, Universitas Sembilanbelas November Kolaka yang telah membimbing penulisan artikel ini.

\section{REFERENSI}

Asnidar, dan Asrida. 2017. Analisis Kelayakan Usaha Home Industry Kerupuk Opak di Desa Paloh Meunasah Dayah Kecamatan Muara Satu Kabupaten Aceh Utara Asnidar. Jurnal S. Pertanian (1) , No.1 : Hal 39-47

Boekoesoe, Y., Murtisari, A., \& Umar, Y. 2015. Analisis kelayakan finansial dan nonfinansial pada usaha kopra di Desa Siduwonge Kecamatan Randangan Kabupaten Pohuwato. Jurnal Perspektif Pembiayaan dan Pembangunan Daerah 2(4): 193-200.

Kindangen, J. G. 2007. Analisis Kelayakan Usaha Pengembangan Industri Kelapa Terpadu Skala Pedesaan di Sulawesi Utara. Jurnal Pengkajian dan Pengembangan Teknologi Pertanian Vol. 10. No 3; Hal 236-249

Kuswanto. 2014. Analisis kelayakan finansial usaha pengolahan produk turunan kelapa di Provinsi Jambi. Jurnal Manajemen Terapan dan Keuangan 1(3): 209-216.

Sukmaya, SG. 2017. Analisis Permintaan Minyak Kelapa (Coconut Crude Oil) Indonesia di Pasar Internasional. Journal of Agribusiness and Rural Development Research 3(1). Setiawan, R. 2002. Direktori Pasar Agrobisnis Dalam dan Luar Negeri. Jakarta: Escaeva.

Setyawan, S., \& Purwanti, E. 2016. Nilai tambah dan profitabilitas komoditas kelapa di Kabupaten Natuna. Riset Akuntansi Keuangan, 1(1), 75-84.

Trubus. 2005. Majalah Pertanian Bulan Juli 2005. 